\title{
Comparison of Three Methods Used in Assessment of Carbohydrate Absorption in Malnourished Children
}

\author{
W. P. T. JAMES \\ From the Department of Human Nutrition, London School of Hygiene and Tropical Medicine, London
}

\begin{abstract}
James, W. P. T. (1972). Archives of Disease in Childhood, 47, 531. Comparison of three methods used in assessment of carbohydrate absorption in malnourished children. The results of oral lactose and sucrose tolerance tests were compared with jejunal disaccharidase activities and the absorption rates of lactose and sucrose from a perfused segment of jejunum in 8 malnourished children before and after treatment.

Treated children, with nearly normal utilization of circulating glucose, showed a good correlation between the oral tolerance test results and the jejunal absorption rates of lactose and sucrose. Malnourished children often showed normal rises in blood glucose despite low disaccharidase activities and poor jejunal absorption rates of glucose, lactose, and sucrose. These rises were considered to reflect poor glucose uptake by peripheral tissues rather than adequate absorption of sugars from the distal small intestine.

Jejunal absorption of lactose and sucrose was only limited by the disaccharidase activities when these were very low; the rate of disaccharide absorption was usually closely related to the rate of glucose absorption, despite a wide range in disaccharidase activities.
\end{abstract}

Several tests have been used in children and adults in an attempt to establish whether patients are able to hydrolyse and absorb the different forms of carbohydrate in the diet.

The 3 clinical methods at present available are the oral tolerance test, the direct measurement on jejunal mucosa of carbohydrase activities, and observations on the faecal $p \mathrm{H}$ and output of water and sugar. Other methods, including hydrogen excretion measurements of the breath, and intubation studies of the small intestine for sampling after feeds or perfusion of the jejunum, are at present used only as research tools.

Diarrhoea is a more prominent feature of carbohydrate intolerance in children than in adults. This difference presumably reflects the importance of the adult colon in reducing the loss of water (Dawson, 1970). Colonic bacterial fermentation, with the production of organic anions from unabsorbed sugar, will also affect the amount of carbohydrate and water in the stool, and this fermentation process may differ in children and adults. In children the severity of the diarrhoea and measure-

Received 3 December 1971. ments of stool carbohydrate and $p \mathrm{H}$ are often used clinically as an indication of sugar intolerance. These signs are not always reliable, however (Holzel, 1967); some children may have surprisingly little diarrhoea but fail to thrive because a portion of their caloric intake cannot be absorbed.

The present investigation examines the usefulness of oral tolerance tests in malnourished children. The results of these tests, together with the jejunal lactase and sucrase activities, are compared with the results obtained from the direct measurement of lactose and sucrose absorption in a segment of perfused jejunum. These 3 methods were used in studies of 8 children, both on admission to hospital with malnutrition and again after two months' treatment in a metabolic ward.

\section{Methods}

Eight children with moderate or severe proteincalorie malnutrition were investigated in a metabolic ward in Kingston, Jamaica. The children's ages varied from 6 to 24 months, and all had a history consistent with an inadequate calorie or protein intake for at least 3 months before admission. Only one child presented with gastroenteritis, but all had had some diarrhoea 
before admission, and there was a history in most cases of several episodes of acute diarrhoea. The one child, Case 2, with gastroenteritis and severe pneumonia, anaemia, and dehydration, required intravenous therapy including blood transfusion. He was not investigated until over 2 weeks after admission when his condition was much improved. No child when tested had severe diarrhoea, and after admission all the children received increasing strengths of small frequent feeds of glucosewater, followed by either a modified milk preparation (Lactogen) with additional sucrose, or a preparation without lactose (Sobee).

Oral tolerance tests. Sugars were given orally for tolerance tests at 8.00 a.m. after a 6-hour fast. Children were lightly sedated 30 minutes before the test and a fasting sample of capillary blood was drawn by heel prick. Children then received orally either $2 \mathrm{~g} / \mathrm{kg}$ sucrose, lactose, or an equivalent mixture of glucose and galactose as a $10 \%$ solution. Capillary blood was then sampled every 30 minutes for 2 hours. If the blood glucose rose less than $30 \mathrm{mg} / 100 \mathrm{ml}$ after the oral sugar, then intolerance was considered likely; increments of less than $20 \mathrm{mg} / 100 \mathrm{ml}$ were considered diagnostic of malabsorption.

The results of the oral lactose and the glucosegalactose tolerance tests were compared by the area ratio method of Cuatrecases, Lockwood, and Caldwell (1965). The increase in the blood glucose above fasting levels after lactose and the equivalent monosaccharide mixture were plotted, and the area under the curve in the lactose test was expressed as a percentage of the corresponding area after glucose and galactose.

Jejunal biopsy. Samples of jejunal mucosa were obtained with a paediatric Watson capsule from the first loop of the jejunum using a simple technique which reduced the time and discomfort to a minimum (James, 1968a). The biopsy sample was immediately divided and one-half, weighing 5-20 mg, was washed in ice cold saline, blotted, and weighed on an electromagnetic balance. All samples were assayed immediately or within 24 hours after storage in dry-ice in a small sealed container. Lactase, sucrase, and maltase were assayed using Burgess et al. (1964) modification of Dahlqvist's technique (1964). Results were expressed as $\mu$ moles disaccharide hydrolysed per minute at $37^{\circ} \mathrm{C}$ and expressed in terms of the wet weight of mucosal tissue (James, 1971).

Jejunal perfusion. These studies were performed on a separate day. Full details have been given elsewhere (James, 1968b, 1970), but in principle the technique involved the passage of a multilumen tube into the jejunum after a short fast. Solutions containing $2 \cdot 5,5 \cdot 0$, or $10 \mathrm{~g} / 100 \mathrm{ml}$ glucose, $5 \mathrm{~g} / 100 \mathrm{ml}$ lactose, or $5 \mathrm{~g} / 100 \mathrm{ml}$ sucrose in $150 \mathrm{mM}$ sodium chloride were infused at $1.5 \mathrm{ml} / \mathrm{min}$ for 2 hours. All solutions contained a nonabsorbable marker, polyethylene glycol, which enabled calculations of sugar absorption rates.

After an hour's equilibration for each solution, samples were gently aspirated from sites 15 and 40 $\mathrm{cm}$ below the infusion point, i.e. in the midjejunum. Collections continued for an hour with each solution so that the average rate of sugar absorption could be found for each sugar. Jejunal absorption rates are presented for the total $40 \mathrm{~cm}$ and expressed as mmoles monosaccharide absorbed per hour. The same method of expression is used for the disaccharides, lactose, and sucrose, since this allows a direct comparison with the absorption rates from the $5 \mathrm{~g} / 100 \mathrm{ml}$ glucose solution and has a physiological basis: the transport of the monosaccharide components of lactose and sucrose is the final part of the absorption of the disaccharides.

\section{Results}

Oral tolerance tests. The lactose tolerance test (Table I, Col. 1 and 2) suggested that the first 2 of the 8 children were intolerant of lactose and also had poor monosaccharide absorption; the next 2 children had lactose intolerance with adequate monosaccharide absorption; the other 4 children were able to absorb both the lactose and the monosaccharides. Thus the 4 children in Group $A$ could be classified as 'lactose nonabsorbers' and the 4 children in Group B as 'lactose absorbers'. The results obtained by the area ratio method were in agreement with the simpler assessment made by oral lactose alone.

After treatment (Table II, Col. 1 and 2) only 1 of the 4 original 'nonabsorbers' failed to recover; in Group B one child, Case 8, had evidence of lactose intolerance, perhaps as a result of a mild episode of gastroenteritis one week before reassessment. Again the area ratio results corresponded to those of oral lactose alone.

The oral tolerance results obtained after sucrose loading are incorporated into Table III. Two of the 3 children tested in Group A ('lactose nonabsorbers') had a normal response to oral sucrose, whereas only 1 of the 3 children in Group B had a normal sucrose tolerance test. Thus lactose and sucrose malabsorption seemed from these tests to occur independently in malnutrition. After treatment all the children responded well to oral sucrose so that defects of both sucrose and lactose absorption, when present in the malnourished child, seemed to recover after several weeks' treatment.

Jejunal absorption. The conclusions drawn from the oral tolerance tests were not completely confirmed when these tests were compared with the direct measurements of jejunal absorption.

When oral tolerance tests gave evidence of intolerance, in general, a low rate of jejunal absorption was found. Several of the other children, however,

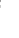


Three Methods Used in Assessment of Carbohydrate Absorption in Malnourished Children 533 TABLE I

Assessment of Lactose Absorption in 8 Malnourished Children, Comparing Oral Tolerance Tests, Jejunal Lactase Activities, and Absorption Rates of Lactose and Glucose from Solutions Perfusing Jejunum

\begin{tabular}{|c|c|c|c|c|c|}
\hline \multirow[b]{2}{*}{ Column } & \multicolumn{2}{|c|}{ Oral Tolerance } & \multirow{2}{*}{$\frac{\text { Biopsy }}{3}$} & \multicolumn{2}{|c|}{ Jejunal Perfusion } \\
\hline & 1 & 2 & & 4 & 5 \\
\hline & $\begin{array}{c}\text { Rise in Blood } \\
\text { Glucose After } \\
\text { Lactose } \\
\text { mg/100 ml }\end{array}$ & $\begin{array}{c}\text { Area Ratio } \\
\text { Lactose to } \\
\text { Monosaccharides } \\
(\%)\end{array}$ & $\begin{array}{l}\text { Lactase } \\
\text { Units per } \\
\text { g wet wt } \\
\text { Mucosa }\end{array}$ & $\begin{array}{l}\text { Lactose Absorption } \\
\text { (mmoles } \\
\text { monosaccharide } / \mathrm{hr} \\
\text { in } 40 \mathrm{~cm} \text { ) }\end{array}$ & $\begin{array}{c}\text { Lactose Absorption } \\
\text { as \% } \\
\text { of Glucose } \\
\text { Absorption }\end{array}$ \\
\hline $\begin{array}{c}\text { Group } A \\
\text { Case } 1^{\star} \\
\text { Case } 2 \\
\text { Case } 3 \\
\text { Case } 4\end{array}$ & $\begin{array}{l}27 \\
18 \\
24 \\
18\end{array}$ & $\begin{array}{c}53 t \\
132 t \\
29 \\
37\end{array}$ & $\begin{array}{l}0 \cdot 1 \\
1 \cdot 7 \\
0 \cdot 9 \\
2 \cdot 3\end{array}$ & $\begin{array}{r}0 \cdot 0 \\
7 \cdot 7 \\
13 \cdot 6 \\
3 \cdot 2\end{array}$ & $\begin{array}{r}0 \\
55 \\
105 \\
21\end{array}$ \\
\hline $\begin{array}{c}\text { Group } B \\
\text { Case } 5^{\star} \\
\text { Case } 6 \\
\text { Case } 7 \\
\text { Case } 8\end{array}$ & $\begin{array}{l}44 \\
43 \\
86 \\
48\end{array}$ & $\begin{array}{l}92 \\
82 \\
81 \\
73\end{array}$ & $\begin{array}{r}0 \cdot 0 \\
13 \cdot 4 \\
2 \cdot 7 \\
1 \cdot 3\end{array}$ & $\begin{array}{r}0 \cdot 2 \\
7 \cdot 9 \\
21 \cdot 1 \\
10 \cdot 6\end{array}$ & $\begin{array}{r}11 \\
71 \\
140 \\
78\end{array}$ \\
\hline
\end{tabular}

Group A, 'lactose nonabsorbers'; Group B, 'lactose absorbers'-see text.

*Only children with a 'flat' mucosa on biopsy.

†Poor response to oral monosaccharides: blood glucose increment $<20 \mathrm{mg} / 100 \mathrm{ml}$.

Note: Lactose and glucose solutions were infused into jejunum at a rate equivalent to 25 mmoles monosaccharide/hr.

who apparently responded well to oral sugar, were also found to have poor mucosal absorption of lactose and sucrose. Table I (Col. 4) shows that all 4 children in Group A had poor jejunal absorption of lactose, but 3 of the 4 so-called 'lactose absorbers' (Group B) also had poor lactose absorption in the jejunum. Thus, severe jejunal malabsorption of lactose could occur in malnourished children with normal increases in blood glucose after oral lactose.

Similarly jejunal sucrose absorption rates were often low despite large responses to oral sucrose (Table III). Whenever sucrose absorption rates were low then lactose absorption was also very poor; sucrose malabsorption did not occur as a selective defect.

Jejunal disaccharidases. The jejunal disaccharidase activities were often lower than expected in several malnourished cases with normal responses to oral sugar. Thus 3 of the 4 'lactose absorbers' in Group B (Table I) with excellent responses to

TABLE II

Comparison of 3 Methods of Assessing Lactose Absorption Capacity in Malnourished Children After Treatment in Hospital

\begin{tabular}{|c|c|c|c|c|c|}
\hline \multirow[b]{2}{*}{ Column } & \multicolumn{2}{|c|}{ Oral Tolerance } & \multirow{2}{*}{$\frac{\text { Biopsy }}{3}$} & \multicolumn{2}{|c|}{ Jejunal Perfusion } \\
\hline & 1 & 2 & & 4 & 5 \\
\hline & $\begin{array}{c}\text { Rise in Blood } \\
\text { Glucose After } \\
\text { Lactose (mg/100 ml) }\end{array}$ & $\begin{array}{c}\text { Area } \\
\text { Ratio } \\
(\%)\end{array}$ & $\begin{array}{l}\text { Lactase } \\
\text { Units per } \\
\text { g wet wt }\end{array}$ & $\begin{array}{c}\text { Lactose Absorption } \\
\text { (mmoles } \\
\text { monos/hr) }\end{array}$ & $\begin{array}{c}\text { Ratio Lactose to } \\
\text { Glucose Absorption } \\
(\%)\end{array}$ \\
\hline $\begin{array}{r}\text { Group } A \\
\text { Case } 1 \\
\text { Case } 2 \\
\text { Case } 3 \\
\text { Case } 4\end{array}$ & $\begin{array}{l}12 \\
42 \\
30 \\
66\end{array}$ & $\begin{array}{r}22 \\
178 \\
55 \\
89\end{array}$ & $\begin{array}{l}0 \cdot 7 \\
2 \cdot 1 \\
1 \cdot 5 \\
2 \cdot 2\end{array}$ & $\begin{array}{l}14 \cdot 3 \\
20 \cdot 5 \\
19 \cdot 9 \\
18 \cdot 3\end{array}$ & $\begin{array}{r}88 \\
83 \\
102 \\
114\end{array}$ \\
\hline $\begin{array}{r}\text { Group } B \\
\text { Case } 5 \\
\text { Case } 6 \\
\text { Case } 7 \\
\text { Case } 8\end{array}$ & $\begin{array}{l}34 \\
60 \\
30 \\
16\end{array}$ & $\begin{array}{r}34 \\
154 \\
288 \\
6\end{array}$ & $\begin{array}{l}3 \cdot 1 \\
9 \cdot 7 \\
5 \cdot 0 \\
0 \cdot 9\end{array}$ & $\begin{array}{r}14 \cdot 9 \\
21 \cdot 0 \\
21 \cdot 5 \\
1 \cdot 8\end{array}$ & $\begin{array}{l}72 \\
99 \\
93 \\
14\end{array}$ \\
\hline
\end{tabular}


Comparison of Results of Sucrose Tolerance Tests, Jejunal Sucrase Assays, and Sucrose Perfusion Studies in 8 Children, Studied Both on Admission and After Treatment

\begin{tabular}{|c|c|c|c|c|c|c|c|c|}
\hline & \multicolumn{4}{|c|}{ Malnourished } & \multicolumn{4}{|c|}{ Treated } \\
\hline & $\begin{array}{c}\text { Rise in } \\
\text { Blood } \\
\text { Glucose } \\
\text { (mg/100 ml) } \\
\text { After Oral } \\
\text { Sucrose }\end{array}$ & $\begin{array}{l}\text { Jejunal } \\
\text { Sucrase } \\
\text { Activity }\end{array}$ & $\begin{array}{c}\text { Sucrose } \\
\text { Absorption } \\
\text { Rate }\end{array}$ & $\begin{array}{c}\text { Sucrose } \\
\text { Absorption } \\
\text { Rate as \% } \\
\text { Glucose } \\
\text { Absorption } \\
\text { Rate }\end{array}$ & $\begin{array}{c}\text { Rise in } \\
\text { Blood } \\
\text { Glucose } \\
\text { (mg/100 ml) } \\
\text { After Oral } \\
\text { Sucrose }\end{array}$ & $\begin{array}{l}\text { Jejunal } \\
\text { Sucrase } \\
\text { Activity }\end{array}$ & $\begin{array}{c}\text { Sucrose } \\
\text { Absorption } \\
\text { Rate }\end{array}$ & $\begin{array}{c}\text { Sucrose } \\
\text { Absorption } \\
\text { Rate as \% } \\
\text { Glucose } \\
\text { Absorption } \\
\text { Rate }\end{array}$ \\
\hline $\begin{array}{r}\text { Group } A \\
\text { Case } 1 \\
\text { Case } 2 \\
\text { Case } 3 \\
\text { Case } 4\end{array}$ & $\frac{10}{62}$ & $\begin{array}{l}0 \cdot 3 \\
1 \cdot 7 \\
1 \cdot 2 \\
7 \cdot 5\end{array}$ & $\begin{array}{r}1 \cdot 4 \\
12 \cdot 5 \\
17 \cdot 0 \\
12 \cdot 0\end{array}$ & $\begin{array}{r}12 \\
91 \\
132 \\
83\end{array}$ & $\begin{array}{l}67 \\
\frac{60}{65}\end{array}$ & $\begin{array}{l}5 \cdot 6 \\
3 \cdot 3 \\
5 \cdot 2 \\
5 \cdot 0\end{array}$ & $\begin{array}{l}11 \cdot 8 \\
24 \cdot 8 \\
24 \cdot 4 \\
16 \cdot 2\end{array}$ & $\begin{array}{r}73 \\
101 \\
125 \\
100\end{array}$ \\
\hline $\begin{array}{c}\text { Group B } \\
\text { Case } 5 \\
\text { Case } 6 \\
\text { Case } 7 \\
\text { Case } 8^{\star}\end{array}$ & $\begin{array}{l}-\overline{26} \\
90 \\
24\end{array}$ & $\begin{array}{l}1 \cdot 0 \\
1 \cdot 7 \\
6 \cdot 3 \\
2 \cdot 7\end{array}$ & $\begin{array}{r}0 \cdot 0 \\
7 \cdot 9 \\
20 \cdot 2 \\
22 \cdot 4\end{array}$ & $\begin{array}{r}0 \\
71 \\
135 \\
165\end{array}$ & $\begin{array}{l}41 \\
48 \\
45 \\
35\end{array}$ & $\begin{array}{l}5 \cdot 4 \\
7 \cdot 2 \\
7 \cdot 3 \\
2 \cdot 5\end{array}$ & $\begin{array}{l}19 \cdot 8 \\
21 \cdot 7 \\
23 \cdot 5 \\
10 \cdot 1\end{array}$ & $\begin{array}{r}98 \\
102 \\
101 \\
77\end{array}$ \\
\hline
\end{tabular}

*An episode of fever and diarrhoea one week before the second series of tests.

Note. Sucrose infusion rate $26.3 \mathrm{mmoles}$ monosaccharide/hr. Absorption rates expressed in the latter units and also as percentage of rate of absorption from a glucose solution infused at $25 \mathrm{mmoles} / \mathrm{hr}$.

oral lactose had lactase activities below 3 units, and one child, Case 5, had no detectable lactose activity at all. Sucrase activities (Table III) were also sometimes low with normal increments in blood glucose after oral sucrose, e.g. Case 2.

The disaccharidase activities as well as the measurements of the jejunal absorption of sugars suggested that the oral tolerance tests in malnourished children were underestimating the number of children with defects in sugar absorption.

When the hydrolytic capacity of the jejunal mucosal disaccharidases was related to the absorption rates of disaccharides perfusing the jejunum, then two distinct phenomena became apparent (Fig.). At low concentrations of disaccharidases there was a conspicuous reduction in sucrose and lactose absorption: below 4 units of lactase or sucrase there was a significant correlation between mucosal hydrolytic activity measured in vitro and jejunal absorption measured in vivo $(P<0.05)$ (James, 1970). With disaccharidase activities above 4 units, however, there were several children, both malnourished and recovered, who failed to absorb the perfusing sugar maximally. All the children with these higher levels of disaccharidase activity should have been able to absorb almost all the sucrose or lactose infused. Four children, with hydrolase values ranging from 5 to 13.4 units, failed to absorb more than $65 \%$ of the sugar infused. Thus, at these levels of disaccharidase activity, the hydrolytic capacity did not seem to be the ratelimiting step in disaccharide absorption.
That the rate of monosaccharide absorption was the rate-limiting step in disaccharide absorption in these children is suggested when the results of lactose and sucrose absorption are compared with the absorption rate from a solution of glucose infused at an equivalent rate, i.e. the $5 \mathrm{~g} / 100 \mathrm{ml}$ solution. If lactase or sucrase were primarily responsible for the malabsorption then the rate

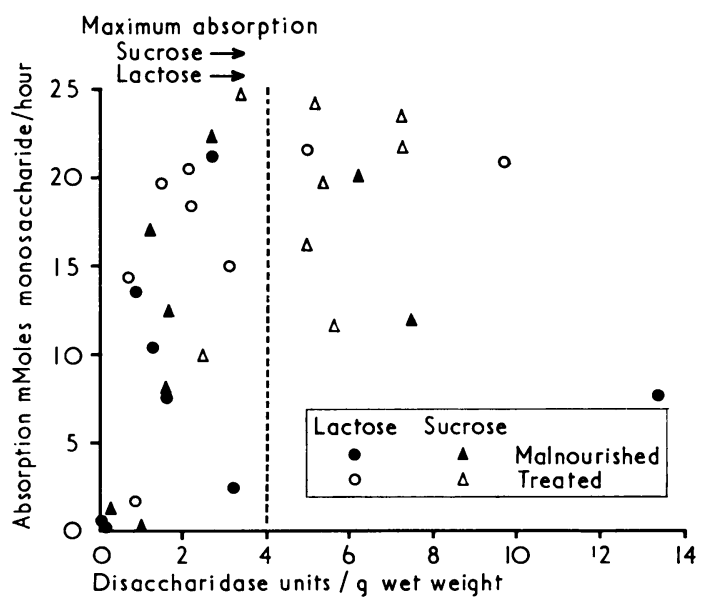

Fig.-Relation between rate of disaccharide absorption from solutions perfusing the jejunum and disaccharidase activity measured in jejunal biopsies. (Relation was significant $(P<0.05)$ for all values below 4 disaccharidase units.) 


\section{Three Methods Used in Assessment of Carbohydrate Absorption in Malnourished Children 535}

of absorption of the disaccharide might be low, e.g. less than $50 \%$ when compared with the absorption from the glucose solution. This comparison is similar to that used in the area ratio method for oral tolerance tests. A low rate of disaccharide absorption, which is still more than $50 \%$ of the glucose absorption rate, suggests that the rate of glucose absorption is at least as important as the disaccharidase activity in limiting the overall absorption of the disaccharide.

Table I (Col. 5) shows that only 3 malnourished children had a selective defect in lactose absorption compared with the glucose absorption rates, but all the malnourished children except one (Case 7) had poor lactose and glucose absorption, i.e. ratios over $50 \%$. Similarly sucrose transport or hydrolysis was particularly limiting in 2 of the 8 malnourished children (Table III, Col. 4), but glucose malabsorption also limited the sucrose absorption of 3 other children.

After treatment there was a striking difference in the results. There was a conspicuous rise in lactose and sucrose absorption, with disaccharide/ glucose ratios of over $70 \%$. The only exception, Case 8, again showed evidence of lactose and sucrose malabsorption after her gastroenteritis.

\section{Discussion}

The methods used for assessing carbohydrate absorption did not include the measurement of the $p \mathrm{H}$ or the sugar content of the stools. These faecal measurements have been found in practice to be useful in controlling the dietary intake of carbohydrate in some malnourished children (Wharton, Howells, and Phillips, 1968; Chandra, Pawa, and Ghai, 1968), though other experience has shown that sugar malabsorption may be associated with very variable amounts of sugar in the faeces and with inconsistent $p \mathrm{H}$ changes (Torres-Pinedo et al., 1966; Holzel, 1967). Faecal $p \mathrm{H}$ and reducing sugar measurements were not made by the author after preliminary investigations showed inconsistent results, particularly in $p \mathrm{H}$ measurements. In rehabilitation centres for malnourished children, where rapid diagnosis of sugar malabsorption is important, testing the stool for reducing sugars with Clinitest tablets is probably the simplest test to use. The amount of carbohydrate present in the stool will be limited by colonic fermentation, and sucrose will not, of course, be detected by this test.

The present work showed that there was no rapid and satisfactory method for assessing the extent of disaccharide absorption in these children. Oral sucrose and lactose tests often seemed to overestimate the degree of sugar absorption when direct assessment of absorption showed that children with a normal response in blood glucose to oral sucrose or lactose had very impaired absorption of these sugars from the jejunum. These findings were consistent with those of Torres-Pinedo and his colleagues (1966) who sometimes found a normal response in blood glucose when $80 \%$ of the sugar ingested had appeared in the stools.

The malnourished children were known to have a very poor uptake of glucose by the peripheral tissues, and an inadequate secretion of insulin (James and Coore, 1970). The rate of disappearance of circulating glucose was much slower in the malnourished state $(\mathrm{kG}=1.95)$ than after treatment $(\mathrm{kG}=2 \cdot 53)$, but these later results were still slower than in normal children $(\mathrm{kG}=$ 3.45). Small amounts of absorbed glucose in the malnourished child could thereforc simulate a normal rate of sugar absorption despite lactase and sucrase deficiency and disaccharide malabsorption. Comparing the lactose with the monosaccharide tolerance tests should overcome this problem, since both tests would be affected by the slow disappearance of circulating glucose. In fact glucose as well as lactose malabsorption frequently occurred, so that no reliable estimate of lactose absorption could be made with the oral tolerance tests. The method of calculating area ratios merely indicated whether lactose malabsorption was more important than poor glucose absorption in determining lactose intolerance.

The normal tolerance test results in these malnourished children with jejunal abnormalities could also mean that sugar absorption was occurring at a lower level of the small intestine than normal. A child, if he absorbs like an adult, absorbs practically all his dietary carbohydrate from the upper small intestine, the lower jejunum and ileum remaining almost sugar free (Borgström et al., 1957). Under conditions of malabsorption, therefore, an excessive amount of sugar enters the lower small intestine where further absorption can take place if the mucosa is undamaged. The state of the malnourished child's ileal mucosa is unknown, but one of the first pathological descriptions of adult malnutrition emphasized the extraordinary thinning of the ileum (Passmore, 1947). Some ileal function presumably does remain, and this will help in increasing the absorptive capacity in these malnourished children. Deterioration in mucosal function may only become evident on testing with oral sugars when the limits of the intestinal reserve for carbohydrate absorption have been reached. 
In some of the children studied, e.g. Cases 1 and 2, with flat jejunal mucosa, the response in blood glucose to oral lactose was surprisingly good, i.e. 27 and $44 \mathrm{mg} / 100 \mathrm{ml}$. Since jejunal lactase activities and lactose absorption from a $40 \mathrm{~cm}$ segment of jejunum were negligible, the response in blood glucose must have been derived from lactose absorbed more distally. It is likely, however, that the severe intolerance to circulating glucose exaggerated the importance of this distal absorption, and that the normal responses in blood glucose reflected the masking of sugar malabsorption rather than showing the full reserve capacity of the distal gut.

The interpretation of measurements of total lactase or sucrase activity in a mucosal biopsy is difficult for several reasons. The lactase measurements on jejunal mucosa include the nonspecific lysosomal enzyme with $\beta$-galactosidase activity, so that the physiologically active brush border lactase may have been present in even lower concentrations. Bowie, Barbezat, and Hansen (1967) have also found that there was greater consistency between oral tolerance tests and mucosal lactase activity if lactase activity was expressed in terms of the mucosal protein content. The use of any of the parameters normally used for calculating activities, including the use of the DNA content of the biopsy as an index of cell number, is imperfect, but the protein content might be useful in oedematous states. In order to avoid this complication, the children in the present series were studied after the clearance of oedema.

When disaccharidase activities measured in biopsy specimens were low, absorption rates of sucrose and lactose were correspondingly reduced. At higher enzyme activities, however, the rate of sucrose and lactose absorption was not always raised. This might indicate that the brush border lactase was making a smaller contribution to total $\beta$-galactosidase activity, or, that the sample of mucosa assayed was unrepresentative of the jejunal mucosa (Anderson, 1966). In addition, the in vitro activity might never be matched physiologically. In theory the penetration of sugars through the covering mucus and glycocalyx might be more rate limiting than the disaccharidase activity or even the subsequent step of monosaccharide transport (Hamilton and McMichael, 1968). In such cases a faster absorption rate of disaccharides than of glucose could occur as with dipeptides and amino acids (Craft et al., 1968). Though a few children showed this phenomenon, most of the children's absorption rates were either limited by the low disaccharidase activities or by the rate of glucose transport.

Despite the severe functional impairment in the jejunum of these malnourished children, all 3 tests showed evidence of the great improvement that was possible in mucosal function with prolonged hospital treatment.

I thank Sister S. M. Donaldson for her invaluable assistance and care of the children, and Miss J. Garel and Miss S. Miles for technical assistance.

\section{REFERENCES}

Anderson, C. M. (1966). Intestinal malabsorption in childhood. Archives of Disease in Childhood, 41, 571.

Borgström, B., Dahlqvist, A., Lundh, G., and Sjövall, J. (1957). Studies of intestinal digestion and absorption in the human. Fournal of Clinical Investigation, 36, 1521.

Bowie, M. D., Barbezat, G. O., and Hansen, J. D. L. (1967). Carbohydrate absorption in malnourished children. American fournal of Clinical Nutrition, 20, 89.

Burgess, E. A., Levin, B., Mahalanabis, D., and Tonge, R. E. (1964). Hereditary sucrose intolerance: levels of sucrase activity in jejunal mucosa. Archives of Disease in Childhood, 39, 431.

Chandra, R. K., Pawa, R. R., and Ghai, O. P. (1968). Sugar intolerance in malnourished infants and children. British Medical fournal, 4, 611.

Craft, I. L., Geddes, D., Hyde, C. W., Wise, I. J., and Matthews, D. M. (1968). Absorption and malabsorption of glycine and glycine peptides in man. Gut, 9, 425.

Cuatrecasas, P., Lockwood, D. H., and Caldwell, J. R. (1965). Lactase deficiency in the adult: a common occurrence. Lancet, $1,14$.

Dahlqvist, A. (1964). Disorders Due to Intestinal Defective Carbohydrate Digestion and Absorption, p. 9. Ed. by P. Durand. Pensiero Scientifico, Rome.

Dawson, A. M. (1970). The absorption of disaccharides. In Modern Trends in Gastroenterology-4, p. 105. Ed. by W. I. Card and B. Creamer. Butterworths, London.

Hamilton, J. D., and McMichael, H. B. (1968). Role of the microvillus in the absorption of disaccharides. Lancet, 2, 154.

Holzel, A. (1967). Sugar malabsorption due to deficiencies of disaccharidase activities and of monosaccharide transport. Archives of Disease in Childhood, 42, 341.

James, W. P. T. (1968a). Jejunal biopsy modified for paediatric use. Lancet, 1, 795.

James, W. P. T. (1968b). Intestinal absorption in protein-calorie malnutrition. Lancet, 1, 333.

James, W. P. T. (1970). Sugar absorption and intestinal motility in children when malnourished and after treatment. Clinical Science, 39, 305.

James, W. P. T. (1971). Jejunal disaccharidase activities in children with marasmus and with kwashiorkor: response to treatment. Archives of Disease in Childhood, 46, 218.

James, W. P. T., and Coore, H. G. (1970). Persistent impairment of insulin secretion and glucose tolerance after malnutrition. American Fournal of Clinical Nutrition, 23, 386.

Passmore, R. (1947). Mixed deficiency diseases in India: a clinical description. Transactions of the Royal Society of Tropical Medicine and Hygiene, 41, 189.

Torres-Pinedo, R., Lavastida, M., Rivera, C. L., Rodriguez, H. and Ortiz, A. (1966). Studies on infant diarrhea. I. A comparison of the effects of milk feeding and intravenous therapy upon the composition and volume of the stool and urine. fournal of Clinical Investigation, 45, 469.

Wharton, B., Howells, G., and Phillips, I. (1968). Diarrhoea in kwashiorkor. British Medical fournal, 4, 608.

Correspondence to Dr. W. P. T. James, Department of Human Nutrition, London School of Hygiene and Tropical Medicine, Keppel Street, London WC1E 7HT. 